Article

\title{
Customer Concentration, Economic Policy Uncertainty and Enterprise Sustainable Innovation
}

\author{
Tingyong Zhong ${ }^{1}$, Yimeng Zuo ${ }^{1, *}$, Fangcheng Sun ${ }^{1, *}$ and Jeoung Yul Lee ${ }^{2,3, *}$ \\ 1 School of Accountancy, Chongqing Technology and Business University, Chongqing 400067, China; \\ Zhongty@ctbu.edu.cn \\ 2 National Research Base of Intelligent Manufacturing Service, Chongqing Technology and Business \\ University, Chongqing 400067, China \\ 3 School of Business Management, Hongik University, Sejong 30016, Korea \\ * Correspondence: zhaoya@ctbu.edu.cn (Y.Z.); fcsun28@ctbu.edu.cn (F.S.); jeoungyul@hongik.ac.kr (J.Y.L.)
}

Received: 17 January 2020; Accepted: 11 February 2020; Published: 13 February 2020

\begin{abstract}
Few studies have addressed how customer concentration affects the decision of a firm's research and development $(\mathrm{R} \& \mathrm{D})$ strategies and then innovation outcome. Using a sample of China's listed companies for the period from 2009 to 2017, this study investigates the relationship between customer concentration and enterprise sustainable innovations, as well as how such the relationship changes with economic policy uncertainty. The findings imply that there is a significant inverted-U-shaped relationship between customer concentration and enterprise sustainable innovations. Under a high level of economic policy uncertainty, the advantage of the customer relationship is maximized. In this context, raising customer concentration significantly promotes enterprise sustainable innovations. Customer concentration affects innovations differently as the equity properties, and locations of enterprises vary under different levels of economic policy uncertainty. Thus, the interval of customer concentration conducive to enterprise innovations differs. The results are robust to econometric techniques that control for endogeneity. Overall, our findings suggest that enterprises build and adjust the customer relationship and improve the driving mechanism for sustainable innovations.
\end{abstract}

Keywords: customer concentration; enterprise sustainable innovation; economic policy uncertainty; enterprise heterogeneity

\section{Introduction}

The extant literature finds a significant association between customer concentration and (1) financing policies and capital structure [1-9], (2) earnings management [10], (3) accounting conservatism [11], (4) mergers and acquisitions [12-16], (5) return predictability [17], (6) information spillover [18,19], and (7) cost of capital [20]. However, few studies have addressed how customer concentration affect the decision of a firm's research and development (R\&D) strategies and then innovation outcome. This study attempts to address this question by exploring different dimensions of customer-supplier relationship dynamics. Sustainable technological innovation is the internal impetus for improving the core competitiveness of a country and facilitating economic growth. In China the report of the 18th Party Congress put forward "to implement the strategy of innovation-driven development" for the first time. Subsequently, the NPC \& CPPCC held in March 2019 listed innovation as an important topic to accelerate the innovation process for enterprises. The Theory of Endogenous Growth claims that economic growth is mainly the output of endogenous forces and not external forces $[21,22]$. This theory indicates that investments in R\&D personnel, innovation, and knowledge can be meaningful contributors to economic growth with positive externalities and spillover effects of 
a knowledge-based economy [23]. The theory has pointed out that R\&D input is an important factor for sustainable technological innovations [24].

China is currently in the stage of emergency and economic transition. Owing to the incomplete capital market and deficient institutional arrangements, China faces distortion in the element market and resource misallocation. Regarding enterprise innovations, enterprises are very cautious about risky and high-input technological innovations, because of the inefficient allocation of innovative resources and deficient innovative intellectual property-compared to other developed countries, China is still behind of the investment on developing innovative intellectual property. When the informal institutions of a country (such as rituals, etiquette, religions, and management) provides good support for enterprises, enterprises play the complementary or substitution role as a strategic response to deficient official systems [25]. For example, enterprises obtain advantages in resource allocation by building the political-merchant relationship, raising the shareholding proportion of big shareholders, and conducting related transactions in the group. Compared with these channels and means, building up the customer relationship helps to collect richer, more effective, and more innovative resources. Scholars who study innovations rarely pay attention to this perspective.

According to statistical data, only $23 \%$ of listed companies in the U.S. had clients who contributed to more than $10 \%$ of sales revenues and important clients between 1980 and 2004 . The statistical data between 2001 and 2014 showed that about $45 \%$ of listed companies made more than $30 \%$ of sales revenues from the top five clients. A high proportion of companies had more than $50 \%$ of sales with the top five clients [26]. Thus, it can be seen that China's listed companies generally have a high customer concentration. The academia has mainly put forward two hypotheses on how customer concentration affects corporate values. The first one is the supply-chain integration hypothesis. The second one is the client risk hypothesis. According to the supply-chain integration hypothesis, a high customer concentration integrates supply chain resources between enterprises on the upper and lower streams and coordinates finance to reduce financial constraints on enterprises [27-29], supervises the managerial staff's opportunist behaviors [30], reduces risks for the stock market crash [31] to increase corporate values. According to the client risk hypothesis, clients in an advantaged transaction status are likely to encroach on and exploit enterprises, which bring potential operation and financial risks for enterprises [32-34], and reduce corporate values. Therefore, enterprises face one difficulty that needs an urgent solution. On one hand, enterprises should set up intimate relationships with clients to accumulate innovative resources. On the other hand, enterprises should reduce customer concentration to avoid operating and financial risks. If the transmission mechanism of enterprise innovations is analyzed from the perspective of customer concentration, what impact does customer concentration have on enterprise sustainable innovations? Is there an appropriate interval of customer concentration that maximizes enterprise sustainable innovations?

It is noteworthy that the influence paths of the customer relationship on enterprise sustainable innovations are likely to be affected by economic policy uncertainty. The so-called economic policy uncertainty refers to economic subjects fail to predict whether, when, and how the government change existing economic policies [35]. Enterprises are important units of the macroscopic economy. A review of China's macroscopic economic policies over the past decade shows that the government faces endogenous contradictions and conflicts between different regulation goals. Correspondingly, there occur significant discretionary choice and wide fluctuations in the frequency of China's economic policy uncertainty. Characterized by a high input, high risks, and long incubation cycle, the innovation input is more sensitive to changes in the macroscopic environment. Does customer concentration affect enterprise sustainable innovations in different ways and achieve different effects under different levels of economic policy uncertainty? How should customer concentration be actively adjusted according to the changes in the external policy environment to facilitate enterprise sustainable innovations?

This paper analyzed China's A-share listed companies from 2009 to 2017 as a sample to conduct theoretical discussions and empirical tests of the above problems. The main contributions are fourfold. Firstly, this paper extends the limited studies on relationship-specific investment, supply chain 
management, and hold-up problems [1,2,36-38]. This result is consistent with Chang et al. [39], who argue that suppliers with high customer concentration are more likely to pursue mutual dependence and cooperation with their customers. Secondly, the paper focused on and analyzed how customer concentration affected enterprise sustainable innovations and relevant effects from the perspective of customer concentration. This study expands this limited area and provides empirical evidence that customer concentration and economic uncertainty have a strong impact on the supplier's process innovation and product innovation. It made up for the deficiency of inadequate research in this regard. Thirdly, the paper revealed the fact that customer concentration affected enterprise innovations differently under different levels of economic policy uncertainty. Finally, the paper divided enterprises into different groups according to their natures of property rights and locations and conducted a grouped test to find how customer concentration affected enterprise innovations under different levels of economic policy uncertainty. It provides theoretical and empirical evidence for enterprises to actively build and adjust appropriate customer relationships, as well as to improve the drive mechanism for sustainable innovations.

\section{Theoretical Background and Hypotheses Development}

\subsection{Customer Concentration and Enterprise Sustainable Innovation}

According to existing literature (e.g., [40]), the customer concentration of enterprises mainly has both a promotional effect and hindrance effect on enterprise innovations. It means the innovation effect of customer concentration doesn't have a positive or negative impact alone.

First of all, we see a positive effect of customer concentration on enterprise innovations. An appropriate level of customer concentration promotes enterprises to have sustainable technological innovations by removing financing constraints and increasing the resource supply [41]. Also, an appropriate level of customer concentration creates the spillover effect of identifying corporate information, sends the signal of stable performances and low default risks to banks, reduces information asymmetry between banks and enterprises, and removes financing constraints [29]. Secondly, the existence of large clients sends to the capital market the sign of effective supply chain integration, good operating status, and low corporate risks, which in turn reduces equity capital costs for enterprises [28]. Furthermore, the Resource Dependence Theory indicates any organization may rely on the external environment because of the need to obtain resources [42-44]. An appropriate customer relationship provides important channels for enterprises to collect innovative resources and raise efficiency [45]. For one thing, customer concentration affects the intimacy between enterprises and clients, which controls both parties' willingness to share resources. As customer concentration improves, enterprises and clients become more reliant on each other [45]. Interest convergence promotes information sharing and business collaboration between both parties. Also, it provides enterprises with technological resources and market information for $R \& D$, namely the client's $R \& D$ spillover effect [45]. For example, HG Technology only supplied low-end light modules before cooperating with Huawei. In subsequent long-term cooperation with Huawei, however, Huawei's leading effect becomes more prominent. It caused HG Technology to increase input in R\&D and particularly become an industrial-leading light module manufacturer under Huawei's leadership; thus, proving the client's R\&D spillover effect.

On the other hand, sustainable technological innovations are characterized by high values, uniqueness, and risks, which make them the core source for enterprises to expand market shares and get extra profits [40]. The higher the customer concentration is, the larger the volume of transactions with large clients is. With the aim of raising market power and increasing long-term profits, enterprises are strongly motivated to seek technological innovations to attract and keep such stable big client resources.

Lastly, Chinese society attaches importance to maintaining interpersonal relationships and social networks. Such social relationship between enterprises and clients falls in the category of vertical relation assets owned by enterprises [46]. Thus, the relationship itself is a resource. It means 
enterprises not only can obtain information from clients on market demands, technological innovations, and policies but also enrich knowledge on market development, technological R\&D, and sustainable innovation management [46]. Therefore, an appropriate improvement in customer concentration enables enterprises to utilize relationship resources in customer structure effectively and thus promotes enterprise sustainable innovations.

However, we also see a negative effect of customer concentration on enterprise innovations. Excessively high customer concentration crowds out the capital input in R\&D and worsens financing constraints, which hinders enterprises from making sustainable technological innovations. For one thing, excessively high customer concentration causes enterprises to be highly reliant on clients and is likely to trigger clients' opportunistic behaviors. Thus enterprises face the risk of being encroached and exploited. For example, clients may demand a cut in the sales price, default corporate loans, and lengthen commercial credit [47]. It undoubtedly encroaches on the profit space of enterprises and weakens their profitability. As a result, innovative resources are "crowded out", forcing enterprises to cut down the input in innovations. On the other hand, high customer concentration means enterprises need to make more relationship-specific investments. In fact, such a specific investment is a commitment made by enterprises to enhance trust in mutual cooperation. As a result, enterprises face potential risks of being entangled. Once the big customer relationship breaks, enterprises will face destructive blows, such as the depreciation of special capital, large-scale bad debts, and loss of the product market. It forces enterprises to take plenty of cash as the tool for preventing and handling risks, rather than input it in innovations. Lastly, the signaling effect suggests a high customer concentration sends the negative signal that enterprises face high risks of being entangled. It enables banks to avoid borrowing risks by following stricter and constrictive borrowing principles. It thus increases financing costs for enterprises, and enterprises eventually cannot afford to invest in innovations continuously.

In sum, customer concentration affects the technological innovations of enterprises to varying degrees before and after a threshold value. With the improvement in customer concentration, the effects of promoting and hindering enterprise sustainable innovations change in opposite directions. In general, customer concentration first plays a promotional role and then a hindrance role. The paper thus put forward the following hypotheses:

Hypothesis 1 (H1): There is an inverted-U-shaped relationship between customer concentration and enterprise innovations.

\subsection{Economic Policy Uncertainty, Customer Concentration, and Enterprise Sustainable Innovation}

According to relevant studies, enterprises are important components of the macroscopic economy, and their operation and decision-making behaviors are affected by the economic policy uncertainty [48-50]. Thus the influence paths on customer concentration rely on the time-varying characteristics of institutional (economic policy) uncertainty.

The institutional uncertainty context can moderate the effects of customer concentration and enterprise innovation if we understand concentrated customer relationship as high-level social capital with major customers and if we do enterprise innovation as organizational innovation [51]. Studies based on institutional theory have argued that different institutional environments and their different institutional environmental uncertainty make enterprises behave differently according to their different institutional environments and their uncertainty contexts [51-53]. Institutional context and its institutional environment specifies the "rules of the game" both formally and informally [53]. This institutional environment context "determines what strategies work best, and induces firms to choose this set of effective strategies" [51] (p.59) and decision-making behaviors.

On one hand, for the high positive relationship between customer concentration and enterprise innovations under high economic policy uncertainty, when the institutional environment uncertainty is high, enterprises tend to depend on their central and local governments to overcome this difficulty situation and vice versa these governments would tend to support enterprises particularly in transition 
economies such as China [51,54]. Especially, as our sample, China's listed companies are usually large enterprises with a high level of customer concentration and have undertaken larger investments on $R \& D$ projects than smaller sized companies in China. Still, China is characterized as a representative transition economy and with a high central government power and a high influence on support for these large listed companies in China. Thus, when institutional environment becomes more uncertain, its central and local governments support their main economic players who are larger enterprises with high social capital of concentrated major customers-for these governments, these major customers are crucial for supporting their economy. In this vein, as a level of institutional uncertainty becomes higher, the institutional support becomes stronger for these major Chinese enterprises with a high level of social capital and a tight network relationship with highly concentrated major customers $[51,54,55]$. As a result, more resources and subsidies from the central and local governments can assist these enterprises to undertake more innovations-related projects. Thus, there is a high positive correlation between customer concentration and enterprise innovations of these China's listed companies under high institutional environment uncertainty.

On the other hand, when the institutional environment uncertainty is changed to become lower, the Chinese central and local governments would not want to that much strong institutional support compared to high institutional environment uncertainty. Rather, these transition-economy governments tend to support these enterprises as a regular basis and routines. So, in this case natural phenomenon can happen in the relationship between customer concentration and enterprise innovations. From the lowest level to the appropriate level of customer concentration, enterprises can have sustainable technological innovations by removing financing constraints and augmenting the resource supply [41]. This appropriate level of customer concentration can provide the signal of the spillover effect for identifying corporate information which results in low default risks to banks, reduces information asymmetry between banks and enterprises [29]. Management and information systems studies support the notion of which these "partners can mutually benefit through more extensive collaboration and coordination efforts" [56] (p.185).

However, too high customer concentration can cause a negative effect on the capital input in R\&D and worsens financing constraints, and this can make enterprise be difficult to massive investments in innovations-related projects. This can also cause let these enterprises highly reliant on the concentrated major customers to be likely to trigger these clients' opportunism [47]. Also, if concentrated major customers become financially difficult, partner enterprises can face the risks of substantial sales reduction and thus causing decrease in resource allocations in R\&D projects in the future [19]. Moreover, customers' vulnerable financial condition can begin "a "death spiral" in which the suppliers' remaining customers in question of their viability, leading to a compounding loss in sales" [56] (p.187) and thus weakening the resources for sustainable innovations.

Therefore, the paper put forward the following research hypotheses for testing:

Hypothesis $2 a(\mathrm{H} 2 a)$ : There is a high positive correlation between customer concentration and enterprise innovations under high economic policy uncertainty.

Hypothesis $2 \boldsymbol{b}(\mathbf{H} 2 b)$ : There is an inverted-U relationship between customer concentration and enterprise innovations under low economic policy uncertainty.

\section{Research Design}

\subsection{Sample Selection and Data}

The study selected A-share listed companies from the Shanghai Stock Exchange and Shenzhen Stock Exchange between 2009 and 2017 as primary research samples. According to the regulations of China Securities Regulatory Committee, Chinese listed companies were required to disclose the proportion of sales brought by the top five clients to the total sales volume since 2007. However, the paper only selected the interval of years after 2009, because there was inadequate data about 
enterprises before 2009. In addition, the following data screenings were carried out: (1) Deleted ST and *ST companies with abnormal financing data; (2) Deleted the financial insurance industry; (3) Deleted the samples with deficient indicators. Eventually, the paper collected annual imbalanced panel observed values of 13,437 companies. The customer concentration, R\&D input, and financial data of listed companies were from the CSMAR database, while all economic policy uncertainty indicators were from the website http://www.policyuncertainty.com. Meanwhile, the paper conducted winsorization of continuous variables on the corporate level in the model at the $1 \%$ quantile to remove the impact of extreme values.

\subsection{Variables}

\subsubsection{Enterprise Innovation (R\&D)}

The technological innovations of enterprises are generally measured through the input method and the output method. Technological innovation results are more affected by endogenous factors and seldom controlled by the managerial staff [57]. Besides, the theoretical part of this paper pays more emphasis on how innovation input affects decision-making behaviors. Therefore, the paper adopted the input method and reflected enterprise innovations through the relative indicator of corporate $R \& D$ input level (R\&D input/operating revenues). Also, the paper adopted $L n R \& D$, the natural logarithm of corporate $R \& D$ input and absolute value indicator, as a proxy variable in the robustness test.

\subsubsection{Customer Concentration (Top 5)}

The paper referred to the study of Chen et al. [28] and measured customer concentration through the proportion of sales with the Top 5 clients to the annual total sales disclosed by the annual reports of listed companies. The indicator reflects the closeness and stability of the relationship between enterprises and main client transactions. In the robustness test, the paper re-measured customer concentration through the proportion of the Top 1 client's sales revenues to the total sales revenues to ensure the results are reliable.

\subsubsection{Economic Policy Uncertainty (Epu)}

Following Hao et al. [58], Gu et al. [50], and Rao and Xu [59], this study reflected the economic policy uncertainty faced by enterprises through the Epu index constructed by Baker et al. [60]. Baker et al. analyzed South China Morning Post, the most-widely circulated English paper of Hong Kong, and recorded the frequency of events concerning monthly economic policy uncertainty events based on text retrieval. The number of identified articles is divided by the total number of articles published in the current month, which worked out China's Epu index (Source of resources: http: //www.policyuncertainty.com/china_monthly.html). This index differs from the measurement variable used by some scholars that adopted the Epu index of local government. The index has a higher continuity and time-varying characteristic because it covers a wider range of central and local zones [49]. Also, the variable has been widely applied to relevant studies, which guarantees the reliability of conclusions. In order to match with other annual variables, the paper first worked out the average arithmetic value of monthly data as the index of annual economic policy uncertainty. Next, this study put forward the dummy variable Epu for economic policy uncertainty. Enterprises whose value is higher than the average value are put into the group of high economic policy uncertainty, while the enterprises smaller than the average value are put in the group of low economic policy uncertainty $(\mathrm{Epu}=0)$.

\subsubsection{Control Variables}

Following the literature of Meng et al. [61], Meng and Shi [62], Jie, and Fang [63], Liu and Liu [64]. Next, the following control variables are added: (1) Size (corporate size); (2) Lev (asset-liability rate); (3) TobinQ (corporate investment opportunity); (4) ROA (Return on Assets); (5) Cf (cash flows from 
operational activities); (6) Age (corporate age); and (7) SOEs (the value of SOEs is 1 if the firm belongs to State-Owed Enterprises (SOEs), otherwise the value equals 0 if a firm belongs to non-SOEs; representing the nature of equity). Besides, the paper introduced two dummy variables, including Industry and Year, to control the industry and annual effects.

We summarized the measurements of variables in Table 1.

Table 1. Measurements of variables.

\begin{tabular}{|c|c|}
\hline Variable & Measurement \\
\hline \multirow{2}{*}{$\mathrm{R} \& \mathrm{D}$} & R\&D input/Operating Revenues \\
\hline & Natural logarithm of R\&D input \\
\hline \multirow{2}{*}{ Top 1 and Top 5} & Sales Revenues of Top 5 Clients/Total Sales Revenues \\
\hline & Sales Revenues of Top 1 Client/Total Sales Revenues \\
\hline Epu & Dummy variable: The value of high Epu is 1 . Otherwise, it is 0 \\
\hline SOEs & $\begin{array}{l}\text { Dummy variable: The value of SOEs is } 1 \text { if the firm belongs to state owed (SOEs), } \\
\text { otherwise the value equals } 0 \text { if a firm belongs to non-SOEs. }\end{array}$ \\
\hline Region & $\begin{array}{c}\text { Dummy variable: The values of Eastern China, Central China, and Western China are } \\
\text { respectively } 1,2 \text {, and } 3\end{array}$ \\
\hline Size & Natural logarithm of firm's year-end total assets \\
\hline Lev & Year-end Total Liabilities/Year-end Total Assets \\
\hline TobinQ & (Equity Market Value + Net Debt Value)/Year-end Total Assets \\
\hline $\mathrm{ROA}$ & Net Profits/Year-end Total Assets \\
\hline Cf & Net cash flows of operating activities/Year-end total assets \\
\hline Age & Year of Handling-Year of Corporate Establishment \\
\hline Year & Dummy variables are used to control the impact of the macroscopic economy. \\
\hline Industry & Dummy variables are used to control the industrial impact. \\
\hline
\end{tabular}

\subsection{Empircal Model Specification}

The paper constructed the following models. Next, it tested the relationship between customer concentration and enterprise innovations through the panel data multiple regression analysis based on panel data and whether there is heterogeneity for such relationships under different levels of economic policy uncertainty.

$$
\begin{aligned}
R \& D_{i, t}=\beta_{0}+ & \beta_{1} \text { Top }_{i, t}+\beta_{2} \text { Top }^{2}{ }_{i, t}+\beta_{3} \text { Controls }_{i, t}+\sum \text { Year } \\
& +\sum \text { Industry }+\varepsilon_{i, t}
\end{aligned}
$$

In Model (1), the explained variable R\&D is the level of R\&D input. The Top 5 and Top $5^{2}$ are respectively the first-order term and quadratic term of customer concentration. According to the former theoretical analysis, there is an inverted-U-shaped relationship between customer concentration and enterprise innovation. Thus it is estimated that $\beta_{1}$ is positive, while $\beta_{2}$ is negative. Also, the above control variables and year and industriy dummy variables are introduced into the model.

$$
R \& D_{i, t}=\beta_{0}+\beta_{1} \text { Top }_{i, t}+\beta_{2} \text { Controls }_{i, t}+\sum \text { Year }+\sum \text { Industry }+\varepsilon_{i, t}
$$

The explained variable R\&D of Model (2) is the innovation input level, and its core explained variable is customer concentration (Top 5). To test H2, for Model (1) and Model (2) respectively, we conducted grouped regression for the relationship between customer concentration and corporate innovation in the group of high economic policy uncertainty and group of low economic policy uncertainty. According to former theoretical analysis, it is estimated that $\beta_{1}$ is positive in Model (2) in 
the group with high economic policy uncertainty. In the group of low economic policy uncertainty, $\beta_{1}$ is positive and $\beta_{2}$ is negative in Model (1).

\section{Empirical Results and Analysis}

\subsection{Descriptive Statistics Analysis}

Table 2 describes the descriptive statistics of the main variables. Thus, it can be seen the average value of R\&D input is 0.04 ; its median value is 0.033 . The samples are distributed on the right slightly. The maximum and minimum values are 0.248 and 0 , respectively. The proportion of sales revenues of the top 5 clients approaches $99 \%$ at the highest and $1.2 \%$ at the lowest; the average value is $30.2 \%$. Thus, it can be seen Chinese listed companies have a high customer concentration, and there are wide differences between enterprises. It accentuates the research significance of this paper. The proportion of sales revenues of Top 1 clients is between $0.7 \%$ and $67.6 \%$; the mean value is $13 \%$. Although the statistics of Top 5 clients are different, these figures show that Chinese enterprises face high customer concentration. According to statistics of the standard variances of other variables, the financial characteristics of enterprises vary.

Table 2. Descriptive statistics of variables.

\begin{tabular}{ccccccc}
\hline Variable & $\mathbf{N}$ & Mean & Mediam & S.D & Min & Max \\
\hline R\&D & 13,437 & 0.0400 & 0.0330 & 0.0420 & 0 & 0.248 \\
Top5 & 13,437 & 0.302 & 0.247 & 0.204 & 0.0120 & 0.989 \\
Top1 & 10,807 & 0.131 & 0.0860 & 0.129 & 0.00700 & 0.676 \\
Epu & 13,437 & 0.455 & 0 & 0.498 & 0 & 1 \\
Size & 13,437 & 22.01 & 21.82 & 1.232 & 19.10 & 25.85 \\
Lev & 13,437 & 0.408 & 0.397 & 0.206 & 0.0470 & 1.010 \\
TobinQ & 13,437 & 2.393 & 1.842 & 1.950 & 0.226 & 11.17 \\
Roa & 13,437 & 0.0470 & 0.0420 & 0.0560 & -0.184 & 0.241 \\
Cf & 13,437 & 0.0420 & 0.0400 & 0.0700 & -0.199 & 0.261 \\
Age & 13,437 & 2.687 & 2.773 & 0.392 & 1.386 & 3.367 \\
\hline
\end{tabular}

\subsection{Results}

\subsubsection{Customer Concentration and Corporate Innovation}

Before an empirical analysis, we perform the multicollinearity test and the VIF statistics (The mean, maximum and minimum of the VIF is 1.39 (Mean), 1.780 (Size) and 1.03 (Big5 rate) respectively. All of the variables are smaller than 5 showing there is little concern for multicollinearity.) shows there is no problem caused by multicollinearity. Then we also conduct a test of the normal distribution of residuals with Shapiro-Wilk test [65] and the $W$ value and $V$ value is 0.989 and 73.71 respectively, and both are significant at $1 \%$; thus showing that the residuals are normal distribution.

Column (1) in Table 3 reports full-sample regression results of Model (1). According to test results, the regression coefficient of customer concentration (Top 5) is positive at the $1 \%$ significance level. The quadratic term (Top $5^{2}$ ) coefficient is negative at the $5 \%$ significance level. In other words, there is a significant inverted-U-shaped relationship between customer concentration and enterprise innovations. According to calculation, its turning point is $53.33 \%$ (assume $0.016-0.015^{*} 2 X=0, X=$ 0.5333). It means an appropriate improvement in customer concentration is conducive for removing financing constraints for enterprises and enhancing resource sharing when customer concentration is lower than the turning point. Thus, enterprises are facilitated to increase input in R\&D and actively carry out innovative activities. When customer concentration rises to the turning point, the customer risk effect plays the dominant role. After that, raising customer concentration may cause high financial and operational risks to enterprises, which prevents their R\&D input and innovative activities. The results in Column (1) of Table 3 basically proved Hypothesis 1 . In addition, simple statistics show that the 
observed values of about $14.08 \%$ of (1892/13437) samples are higher than the critical value of $53.33 \%$. Even though these listed companies face the problem of high customer concentration, they can hardly play the role of facilitating corporate sustainable innovations through customer concentration. Indeed, the positive relationship between customer concentration and innovation is consistent with previous literature $[40,66,67]$. Especially, Chen [68], who constructs a theoretical framework that models the impact of buyer power on a supplier's product innovation and process innovation by identifying the sources of buyer power and the channels through which buyer power manifests. Krolikowski and Yuan [66] find that close ties between customers and suppliers increase collaboration and information sharing, facilitating R\&D investments.

Table 3. Economic policy uncertainty, customer concentration, and enterprise innovation.

\begin{tabular}{cccccc}
\hline & Full Sample & \multicolumn{2}{c}{ High Uncertainty } & \multicolumn{2}{c}{ Low Uncertainty } \\
\cline { 2 - 6 } & $\mathbf{( 1 )}$ & $\mathbf{( 2 )}$ & $\mathbf{( 3 )}$ & $\mathbf{( 4 )}$ & $\mathbf{( 5 )}$ \\
& $\mathbf{R} \& \mathbf{D}$ & $\mathbf{R} \& \mathbf{D}$ & $\mathbf{R} \& \mathbf{D}$ & $\mathbf{R} \& \mathbf{D}$ & $\mathbf{R} \& \mathbf{D}$ \\
\hline Top5 & $0.016^{* * *}$ & $0.006^{* *}$ & 0.011 & 0.002 & $0.021^{* * *}$ \\
& $(2.98)$ & $(2.21)$ & $(1.33)$ & $(0.94)$ & $(2.98)$ \\
Top5 & $-0.015^{* *}$ & & -0.007 & & $-0.023^{* * *}$ \\
& $(-2.23)$ & & $(-0.64)$ & & $(-2.74)$ \\
Size & $0.001^{* * *}$ & $0.001^{*}$ & $0.001^{* *}$ & $0.001^{* * *}$ & $0.001^{* * *}$ \\
& $(3.73)$ & $(1.90)$ & $(2.01)$ & $(2.76)$ & $(3.26)$ \\
Lev & $-0.046^{* * *}$ & $-0.045^{* * *}$ & $-0.045^{* * *}$ & $-0.046^{* * *}$ & $-0.046^{* * *}$ \\
& $(-19.80)$ & $(-13.10)$ & $(-13.10)$ & $(-14.78)$ & $(-14.85)$ \\
TobinQ & $0.004^{* * *}$ & $0.004^{* * *}$ & $0.004^{* * *}$ & $0.005^{* * *}$ & $0.005^{* * *}$ \\
& $(13.79)$ & $(8.35)$ & $(8.38)$ & $(10.96)$ & $(11.07)$ \\
Roa & $-0.088^{* * *}$ & $-0.096^{* * *}$ & $-0.095^{* * *}$ & $-0.084^{* * *}$ & $-0.083^{* * *}$ \\
& $(-9.54)$ & $(-6.66)$ & $(-6.62)$ & $(-7.09)$ & $(-7.03)$ \\
Cf & $-0.018^{* * *}$ & $-0.032^{* * *}$ & $-0.031^{* * *}$ & -0.007 & -0.006 \\
& $(-3.76)$ & $(-4.22)$ & $(-4.16)$ & $(-1.22)$ & $(-1.01)$ \\
Age & $-0.012^{* * *}$ & $-0.013^{* * *}$ & $-0.013^{* * *}$ & $-0.012^{* * *}$ & $-0.012^{* * *}$ \\
& $(-13.44)$ & $(-8.92)$ & $(-8.92)$ & $(-10.12)$ & $(-10.04)$ \\
Year & control & control & control & control & control \\
Ind & control & control & control & control & control \\
Constant & $0.023^{* * *}$ & $0.043^{* * *}$ & $0.041^{* * *}$ & $0.026^{* *}$ & $0.019^{*}$ \\
& $(2.82)$ & $(3.46)$ & $(3.20)$ & $(2.53)$ & $(1.79)$ \\
N & 13,437 & 6120 & 6120 & 7317 & 7317 \\
Adi_R2 & 0.320 & 0.311 & 0.311 & 0.326 & 0.327 \\
\hline
\end{tabular}

Note: This table presents regression results. The dependent variable is R\&D intensity, measured as the ratio of $R \& D$ expenditures divided by operating revenues. All the regressions control for year fixed effects. The t-statistics in parentheses are based on robust standard errors clustered at the firm level. ${ }^{*}, * *$, and ${ }^{* *}$ indicate statistical significance at the $10 \%, 5 \%$, and $1 \%$ level, respectively.

\subsubsection{Economic Policy Uncertainty, Customer Concentration, and Enterprise Innovation}

The Columns (2) to (5) in Table 3 list the results of grouped regression in Model (1) and Model (2). According to the test, there are significantly high positive correlations between customer concentration and enterprise innovations in the group with high economic policy uncertainty $(\mathrm{Epu}=1)$, but there is no inverted-U-shaped relationship. In the group with a low economic policy uncertainty $(\mathrm{Epu}=0)$, there is a significant $U$-shaped relationship between customer concentration and enterprise innovation. Its positive linear relationship is insignificant, which supports Hypothesis 2a and Hypothesis $2 \mathrm{~b}$. This finding is consistent with literature [69-71]. As mentioned by former theories, under high economic policy uncertainty, enterprises face severer financing constraints and agency contradictions. Also, it creates a larger negative impact on the operating activities and product market. In this context, enterprises are more inclined to resist the impacts of the external environment through resource advantages brought by the customer relationship, yet neglect the negative impact brought by high customer concentration. In this sense, the higher the customer concentration, the more it helps 
enterprises to get external financing and other innovative resources and promote $R \& D$ activities. According to calculation, the turning point is $45.65 \%$ under low economic policy uncertainty. Therefore, the customer concentration of $45.65 \%$ helps enterprises to make innovations.

\subsection{Robust Test}

\subsubsection{Endogenous Test}

A series of tests were carried out for the validity of instruments to prevent estimation results from being inconsistent. The research results of the former part do not support the causality between customer orientation and corporate innovations but may cause endogeneity problems due to reverse causality. Therefore, the paper conducted re-appraisal with Two-Stage Least Squares (2SLS) (2SLS is used as an alternative approach when we face endogenity issue in a regression. When an explanatory variable correlates with an error term, then endogenity problem occurs. At this time, we can use 2SLS where we use an instrumental variable [32,33]).

Following Cao et al. [72] and Wang et al. [73], the industrial average customer concentration of one lagged stage was adopted as an instrument variable in 2SLS estimation. On one hand, the average customer concentration in the industry reflects the general business mode and customer relationship characteristics. It has an impact on the customer concentration of one enterprise and meets the validity nature of the instrument variable. On the other hand, the decision-making for innovation input is determined by corporate strategy, operating status, and financial status. It is not affected by the average industrial customer concentration and meets the endogenous nature of the instrument variable. In Model (1), customer concentration (Top 5) and the quadratic term (Top $5^{2}$ ) are used as endogenous variables. The average customer concentration of an industry and its quadratic term are used as instrumental variables to conduct the 2SLS. Meanwhile, the Durbin-Wu-Hausman test shows the statistical value is $252.486(\mathrm{P}=0.000)$, meaning the customer concentration (Top 5) and its quadratic term (Top $5^{2}$ ) are endogenous explained variables. The statistics of Kleibergen-Paap RK LM is $107.812(\mathrm{P}=0.000)$, meaning there is no unidentified problem. In the first stage, the minimum Eigen value statistic of regression is 203.191. The common empirical rule is that there is no weak instrument variable when the statistical value is greater than 10 . Thus the instrument variables selected by the paper are valid. The Column (1) of Table 4 shows the full-sample 2SLS regression results after mitigating endogenous issues. The inverted-U-shaped relationship between customer concentration and enterprise innovations is still valid, and its significance level is raised to $1 \%$, meaning former conclusions are supported. Similarly, the 2SLS regression results after differentiating economic policy uncertainty proved former conclusions, and the significance level is raised.

In reference to Meng et al.'s study [61], the paper adopted the lagged customer concentration as the explanatory variable to mitigate the endogenous problem caused by reverse causality. All regression results are shown from Column (4) to Column (6) in Table 4. In full-sample regression results and grouped regression results, the first-order term (Top 5) and quadratic term (Top $5^{2}$ ) of customer concentration are still significant, which support former conclusions.

\subsubsection{Quantile Regression}

With the aim of removing the impact of extreme values, the paper tested the relationship between customer concentration and enterprise innovations in full samples through the quantile regression. The quantile regression offers regression results in different conditions. Eventually, three representative quantiles are selected, including 0.25, 0.50, and 0.75. All regression results are shown in Column (1) to Column (3) in Table 5. As the level of input in R\&D changes on different quantiles of the conditional distribution, the first-order term (TOP 5) and the quadratic term (Top $5^{2}$ ) of the regression coefficient are significantly positive and negative at the $1 \%$ level respectively. In other words, there is an inverted-U-shaped relationship between customer concentration changes and enterprise innovations following changes in the quantile level. It proved Hypothesis 1 consistently. It is noteworthy that 
the turning points of the inverted-U-shaped relationship are respectively $48.21 \%, 46.30 \%$, and $43.75 \%$. It means the more enterprises input in $R \& D$, the lower the critical value of the negative impact of customer concentration on enterprise innovations. Enterprises with higher input in R\&D may have better operating status and significant resource endowment advantages.

Table 4. Robust test 1.

\begin{tabular}{|c|c|c|c|c|c|c|}
\hline & \multicolumn{3}{|c|}{ TSLS } & \multicolumn{3}{|c|}{ Lag 1 of Dependent Veriebles } \\
\hline & Full Sample & Epu $=1$ & $\mathrm{Epu}=0$ & Full Sample & $\mathrm{Epu}=1$ & $\mathrm{Epu}=0$ \\
\hline & $\begin{array}{c}\text { R\&D } \\
(1)\end{array}$ & $\begin{array}{c}\text { R\&D } \\
(2)\end{array}$ & $\begin{array}{c}\text { R\&D } \\
\text { (3) }\end{array}$ & $\begin{array}{c}\text { R\&D } \\
\text { (4) }\end{array}$ & $\begin{array}{c}\text { R\&D } \\
(5)\end{array}$ & $\begin{array}{c}\text { R\&D } \\
(6)\end{array}$ \\
\hline Top5 & $\begin{array}{c}0.3163^{* * *} \\
(11.62)\end{array}$ & $\begin{array}{c}0.1028^{* * *} \\
(13.71)\end{array}$ & $\begin{array}{c}0.2899^{* * *} \\
(9.10)\end{array}$ & $\begin{array}{c}0.019^{* * *} \\
(3.18)\end{array}$ & $\begin{array}{c}0.008^{* * *} \\
(2.78)\end{array}$ & $\begin{array}{c}0.020^{* * *} \\
(2.67)\end{array}$ \\
\hline Top5 ${ }^{2}$ & $\begin{array}{c}-0.2811^{* * *} \\
(-8.19)\end{array}$ & & $\begin{array}{c}-0.2595^{* * *} \\
(-6.61)\end{array}$ & $\begin{array}{c}-0.017 * * \\
(-2.37)\end{array}$ & & $\begin{array}{c}-0.022 * * \\
(-2.45)\end{array}$ \\
\hline Size & $\begin{array}{c}0.0062^{* * *} \\
(11.51)\end{array}$ & $\begin{array}{c}0.0039^{* * *} \\
(5.84)\end{array}$ & $\begin{array}{c}0.0060^{* * *} \\
(8.78)\end{array}$ & $\begin{array}{c}0.002^{* * *} \\
(4.38)\end{array}$ & $\begin{array}{c}0.001 \text { ** } \\
(1.98)\end{array}$ & $\begin{array}{c}0.002 * * * \\
(4.22)\end{array}$ \\
\hline Lev & $\begin{array}{c}-0.0522 * * * \\
(-19.31)\end{array}$ & $\begin{array}{c}-0.0506^{* * *} \\
(-12.80)\end{array}$ & $\begin{array}{c}-0.0529 * * * \\
(-14.67)\end{array}$ & $\begin{array}{c}-0.049 * * * \\
(-19.92)\end{array}$ & $\begin{array}{l}-0.047^{* * *} \\
(-12.27)\end{array}$ & $\begin{array}{c}-0.050 * * * \\
(-15.73)\end{array}$ \\
\hline TobinQ & $\begin{array}{c}0.0042^{* * * *} \\
(11.42)\end{array}$ & $\begin{array}{c}0.0035^{* * *} \\
(6.13)\end{array}$ & $\begin{array}{c}0.0042^{* * *} \\
(9.45)\end{array}$ & $\begin{array}{c}0.004^{* * *} \\
(13.47)\end{array}$ & $\begin{array}{c}0.005^{* * *} \\
(8.31)\end{array}$ & $\begin{array}{c}0.004^{* * *} \\
(10.81)\end{array}$ \\
\hline Roa & $\begin{array}{c}-0.0740^{* * *} \\
(-7.00)\end{array}$ & $\begin{array}{c}-0.0858^{* * *} \\
(-5.59)\end{array}$ & $\begin{array}{c}-0.0705^{* * *} \\
(-5.17)\end{array}$ & $\begin{array}{c}-0.092^{* * * *} \\
(-9.41)\end{array}$ & $\begin{array}{c}-0.108^{* * *} \\
(-6.84)\end{array}$ & $\begin{array}{c}-0.081^{* * * *} \\
(-6.67)\end{array}$ \\
\hline $\mathrm{Cf}$ & $\begin{array}{c}0.0187^{* * *} \\
(2.90)\end{array}$ & $\begin{array}{l}-0.0044 \\
(-0.49)\end{array}$ & $\begin{array}{c}0.0239 * * * \\
(2.91)\end{array}$ & $\begin{array}{c}-0.018^{* * *} \\
(-3.40)\end{array}$ & $\begin{array}{c}-0.029 * * * \\
(-3.47)\end{array}$ & $\begin{array}{l}-0.009 \\
(-1.32)\end{array}$ \\
\hline Age & $\begin{array}{c}-0.0109^{* * *} \\
(-9.81)\end{array}$ & $\begin{array}{c}-0.0109^{* * *} \\
(-6.62)\end{array}$ & $\begin{array}{c}-0.0107^{* * *} \\
(-7.41)\end{array}$ & $\begin{array}{l}-0.012 * * * \\
(-12.26)\end{array}$ & $\begin{array}{c}-0.012 * * * \\
(-7.63)\end{array}$ & $\begin{array}{c}-0.012^{* * * *} \\
(-9.61)\end{array}$ \\
\hline Year & Control & Control & Control & Control & Control & Control \\
\hline Ind & Control & Control & Control & Control & Control & Control \\
\hline Constant & $\begin{array}{c}-0.1183^{* * *} \\
(-7.85)\end{array}$ & $\begin{array}{c}-0.0413^{* *} \\
(-2.56)\end{array}$ & $\begin{array}{c}-0.1159 * * * \\
(-6.04)\end{array}$ & $\begin{array}{c}0.015 * \\
(1.67)\end{array}$ & $\begin{array}{c}0.040 * * * \\
(2.98)\end{array}$ & $\begin{array}{l}0.016 \\
(1.40)\end{array}$ \\
\hline $\mathrm{N}$ & 12,325 & 5890 & 6435 & 12,083 & 5427 & 6656 \\
\hline Adi_R2 & 0.0855 & 0.114 & 0.129 & 0.317 & 0.305 & 0.324 \\
\hline
\end{tabular}

Note: All the regressions control for year fixed effects. The t-statistics in parentheses are based on robust standard errors clustered at the firm level. ****, and ${ }^{* * *}$ indicate statistical significance at the $10 \%, 5 \%$, and $1 \%$ level, respectively.

\subsubsection{Change the Core Variable}

The paper adopted the proportion of Top 1 to total sales revenues as the substitution variable for customer concentration and used it in the full-sample regression of Model (1). All testing results are shown in Column (4) of Table 5. Although the first-term (Top 1) and quadratic term (Top $1^{2}$ ) coefficients of customer concentration have lower significance, they generally support the above conclusions on the whole. Next, the natural logarithm of corporate R\&D input, namely LnR\&D, is used as the substitution variable for enterprise innovations and placed into Model (1). According to the test results of Column (5) in Table 5, the conclusions of the former part are robust.

\subsection{Further Studies Based on Enterprise Heterogeneity}

Due to different natures of property rights, companies have widely different resource allocation advantages, risk-taking levels, and agency contradictions. Besides, the companies located in different positions face different official institutional environments, element markets, and financial markets with varying degrees of vitality. Therefore, the property rights and regional heterogeneity of enterprises inevitably lead to distinctive differences in the decision-making for innovation input. It is necessary to discuss the differences between the impacts of customer concentration on enterprise innovations when enterprises have different equity natures, are located in different positions, and face different levels of economic policy uncertainty. 
Table 5. Robust test 2.

\begin{tabular}{|c|c|c|c|c|c|}
\hline & \multicolumn{3}{|c|}{ Quantile Regression } & \multirow[t]{2}{*}{ Change the D.V } & \multirow[t]{2}{*}{ Change the ID.V } \\
\hline & 0.25 & 0.5 & 0.75 & & \\
\hline & $\begin{array}{l}R \& D \\
\text { (1) }\end{array}$ & $\begin{array}{l}\text { R\&D } \\
\text { (2) }\end{array}$ & $\begin{array}{c}R \& D \\
(3)\end{array}$ & $\begin{array}{c}R \& D \\
(4)\end{array}$ & $\begin{array}{c}\text { LnR\&D } \\
\text { (5) }\end{array}$ \\
\hline Top5 & $\begin{array}{c}0.027^{* * *} \\
(10.25)\end{array}$ & $\begin{array}{c}0.025^{* * *} \\
(10.04)\end{array}$ & $\begin{array}{c}0.014^{* * *} \\
(3.20)\end{array}$ & & $\begin{array}{c}0.603^{* * *} \\
(3.30)\end{array}$ \\
\hline Top5 $5^{2}$ & $\begin{array}{c}-0.028 \text { *** } \\
(-9.42)\end{array}$ & $\begin{array}{c}-0.027^{* * *} \\
(-9.18)\end{array}$ & $\begin{array}{c}-0.016^{* * *} \\
(-3.10)\end{array}$ & & $\begin{array}{c}-0.953^{* * *} \\
(-4.56)\end{array}$ \\
\hline Top1 & & & & $\begin{array}{c}0.014^{*} \\
(1.85)\end{array}$ & \\
\hline Top $1^{2}$ & & & & $\begin{array}{c}-0.023 * \\
(-1.69)\end{array}$ & \\
\hline Size & $\begin{array}{c}-0.001 * * * \\
(-7.20)\end{array}$ & $\begin{array}{c}-0.001 * * * \\
(-3.58)\end{array}$ & $\begin{array}{c}0.001^{* *} \\
(2.42)\end{array}$ & $\begin{array}{c}0.001 * * * \\
(3.12)\end{array}$ & $\begin{array}{c}0.841 \text { *** } \\
(59.95)\end{array}$ \\
\hline Lev & $\begin{array}{c}-0.022 * * * \\
(-18.50)\end{array}$ & $\begin{array}{c}-0.021 \text { *** } \\
(-20.24)\end{array}$ & $\begin{array}{c}-0.034^{* * *} \\
(-17.66)\end{array}$ & $\begin{array}{c}-0.051^{* * *} \\
(-19.86)\end{array}$ & $\begin{array}{c}-0.436^{* * *} \\
(-5.65)\end{array}$ \\
\hline TobinQ & $\begin{array}{c}0.0011^{* * *} \\
(6.31)\end{array}$ & $\begin{array}{c}0.002^{* * *} \\
(12.91)\end{array}$ & $\begin{array}{c}0.005^{* * * *} \\
(13.00)\end{array}$ & $\begin{array}{c}0.004^{* * * *} \\
(12.62)\end{array}$ & $\begin{array}{c}0.022^{* * * *} \\
(2.91)\end{array}$ \\
\hline Roa & $\begin{array}{c}0.011^{* * *} \\
(2.64)\end{array}$ & $\begin{array}{c}-0.016^{* * * *} \\
(-4.34)\end{array}$ & $\begin{array}{c}-0.079^{* * *} \\
(-10.65)\end{array}$ & $\begin{array}{c}-0.090 * * * \\
(-8.76)\end{array}$ & $\begin{array}{c}2.588^{* * *} \\
(10.27)\end{array}$ \\
\hline $\mathrm{Cf}$ & $\begin{array}{c}-0.008^{* * *} \\
(-3.04)\end{array}$ & $\begin{array}{c}-0.015^{* * *} \\
(-6.27)\end{array}$ & $\begin{array}{c}-0.021 * * * \\
(-5.43)\end{array}$ & $\begin{array}{c}-0.016^{* * *} \\
(-3.02)\end{array}$ & $\begin{array}{c}0.637 * * * \\
(3.15)\end{array}$ \\
\hline Age & $\begin{array}{c}-0.007^{* * *} \\
(-13.65)\end{array}$ & $\begin{array}{c}-0.008^{* * *} \\
(-15.68)\end{array}$ & $\begin{array}{c}-0.009 * * * \\
(-10.42)\end{array}$ & $\begin{array}{c}-0.011 * * * \\
(-10.96)\end{array}$ & $\begin{array}{c}-0.418^{* * *} \\
(-15.53)\end{array}$ \\
\hline Year & control & control & control & control & control \\
\hline Ind & control & control & control & control & control \\
\hline Constant & $\begin{array}{c}0.043^{* * *} \\
(9.89)\end{array}$ & $\begin{array}{c}0.039 * * * \\
(8.54)\end{array}$ & $\begin{array}{c}0.026^{* * *} \\
(3.09)\end{array}$ & $\begin{array}{c}0.021 \text { ** } \\
(2.40)\end{array}$ & $\begin{array}{c}-1.747^{* * *} \\
(-5.46)\end{array}$ \\
\hline $\mathrm{N}$ & 13,437 & 13,437 & 13,437 & 10,811 & 13,437 \\
\hline Adi_R2 & & & & & 0.455 \\
\hline Pseudo R2 & 0.175 & 0.177 & 0.220 & 0.323 & \\
\hline
\end{tabular}

Note: All the regressions control for year fixed effects. The t-statistics in parentheses are based on robust standard errors clustered at the firm level. * **, and ${ }^{* * *}$ indicate statistical significance at the $10 \%, 5 \%$, and $1 \%$ level, respectively.

\subsubsection{Grouping by Nature of Property Rights}

Regression results are shown in Columns (1) to (4) in Table 6. Under high economic policy uncertainty, there are significant positive correlations between customer concentration and enterprise innovations in the non-SOE group (State $=0$ ), while the significant inverted-U-shaped relationship between customer concentration and enterprise innovations in the SOE group. Test results are listed in Columns (5) to (8) in Table 6. Under low economic policy uncertainty, there is a significant inverted-U-shaped relationship between customer concentration and enterprise innovations in SOEs group $($ State $=1$ ) and non-SOE group (State $=0$ ). Meanwhile, the Suest test, which was similar to the irrelevant model, was adopted to test the between-group difference of Top $5^{2}$ coefficients of SOEs. It was found P $>0.8458$ (Column (2) and Column (6)).

In other words, there is no between-group difference. There may be one possible explanation. Compared with SOEs that have a natural governmental background and resource allocation advantage, non-SOEs face discrimination in credit loans, regulation, and protection of property rights. Under high economic policy uncertainty, non-SOEs are shorter of effective guarantees from official systems. Besides, these enterprises are generally in a highly-competitive environment, which creates stronger innovations, impetus, and abilities. Therefore, the opportunity of profiting from a high uncertainty environment has a stronger appeal to non-SOEs. Therefore, building close customer relationships is an effective means for non-SOEs to get innovative resources in an unfavorable environment. 
Table 6. Customer concentration and enterprise innovation (grouped by nature of property right).

\begin{tabular}{|c|c|c|c|c|c|c|c|c|}
\hline & \multicolumn{4}{|c|}{ Epu $=1$} & \multicolumn{4}{|c|}{ Epu $=0$} \\
\hline & \multicolumn{2}{|c|}{ State $=1$} & \multicolumn{2}{|c|}{ State $=0$} & \multicolumn{2}{|c|}{ State $=1$} & \multicolumn{2}{|c|}{ State $=0$} \\
\hline & (1) & (2) & (3) & (4) & (5) & (6) & (7) & (8) \\
\hline & $R \& D$ & $R \& D$ & R\&D & $R \& D$ & $R \& D$ & $R \& D$ & $R \& D$ & $R \& D$ \\
\hline Top5 & $\begin{array}{l}0.003 \\
(1.00)\end{array}$ & $\begin{array}{c}0.022 * * \\
(2.30)\end{array}$ & $\begin{array}{l}0.007^{*} \\
(1.90)\end{array}$ & $\begin{array}{l}0.003 \\
(0.24)\end{array}$ & $\begin{array}{l}0.003 \\
(1.04)\end{array}$ & $\begin{array}{c}0.024^{* * *} \\
(3.01)\end{array}$ & $\begin{array}{l}0.002 \\
(0.52)\end{array}$ & $\begin{array}{c}0.021^{* *} \\
(2.13)\end{array}$ \\
\hline Top $5^{2}$ & & $\begin{array}{c}-0.022 * * \\
(-2.00)\end{array}$ & & $\begin{array}{l}0.005 \\
(0.29)\end{array}$ & & $\begin{array}{c}-0.024^{* * *} \\
(-2.74)\end{array}$ & & $\begin{array}{c}-0.025^{* *} \\
(-1.98)\end{array}$ \\
\hline Size & $\begin{array}{l}-0.001 \\
(-1.49)\end{array}$ & $\begin{array}{l}-0.001 \\
(-1.13)\end{array}$ & $\begin{array}{c}0.003^{* * *} \\
(3.26)\end{array}$ & $\begin{array}{c}0.003^{* * *} \\
(3.23)\end{array}$ & $\begin{array}{c}-0.002 * * * \\
(-3.60)\end{array}$ & $\begin{array}{c}-0.002^{* * *} \\
(-3.04)\end{array}$ & $\begin{array}{c}0.005^{* * *} \\
(6.02)\end{array}$ & $\begin{array}{c}0.005^{* * *} \\
(6.37)\end{array}$ \\
\hline Lev & $\begin{array}{c}-0.028^{* * *} \\
(-5.50)\end{array}$ & $\begin{array}{c}-0.028^{* * *} \\
(-5.49)\end{array}$ & $\begin{array}{c}-0.053^{* * *} \\
(-11.72)\end{array}$ & $\begin{array}{c}-0.053^{* * *} \\
(-11.72)\end{array}$ & $\begin{array}{c}-0.017^{* * * *} \\
(-4.12)\end{array}$ & $\begin{array}{c}-0.017^{* * *} \\
(-4.16)\end{array}$ & $\begin{array}{c}-0.064^{* * *} \\
(-14.84)\end{array}$ & $\begin{array}{c}-0.064^{* * *} \\
(-14.89)\end{array}$ \\
\hline TobinQ & $\begin{array}{l}0.001 \\
(1.16)\end{array}$ & $\begin{array}{l}0.001 \\
(1.23)\end{array}$ & $\begin{array}{c}0.005^{* * *} \\
(8.46)\end{array}$ & $\begin{array}{c}0.005^{* * *} \\
(8.45)\end{array}$ & $\begin{array}{c}0.003^{* * *} \\
(3.32)\end{array}$ & $\begin{array}{c}0.003^{* * *} \\
(3.39)\end{array}$ & $\begin{array}{c}0.006^{* * *} \\
(10.90)\end{array}$ & $\begin{array}{c}0.006^{* * *} \\
(11.01)\end{array}$ \\
\hline Roa & $\begin{array}{l}-0.012 \\
(-0.64)\end{array}$ & $\begin{array}{l}-0.011 \\
(-0.58)\end{array}$ & $\begin{array}{c}-0.133^{* * *} \\
(-7.00)\end{array}$ & $\begin{array}{c}-0.133^{* * *} \\
(-6.99)\end{array}$ & $\begin{array}{l}-0.003 \\
(-0.18)\end{array}$ & $\begin{array}{l}-0.002 \\
(-0.10)\end{array}$ & $\begin{array}{c}-0.134^{* * *} \\
(-8.20)\end{array}$ & $\begin{array}{c}-0.134^{* * *} \\
(-8.21)\end{array}$ \\
\hline $\mathrm{Cf}$ & $\begin{array}{c}-0.056^{* * *} \\
(-4.92)\end{array}$ & $\begin{array}{c}-0.054^{* * * *} \\
(-4.68)\end{array}$ & $\begin{array}{c}-0.020 \\
(-2.05)\end{array}$ & $\begin{array}{c}-0.020 \text { ** } \\
(-2.11)\end{array}$ & $\begin{array}{l}-0.009 \\
(-1.06)\end{array}$ & $\begin{array}{l}-0.008 \\
(-0.94)\end{array}$ & $\begin{array}{l}-0.002 \\
(-0.26)\end{array}$ & $\begin{array}{l}-0.001 \\
(-0.08)\end{array}$ \\
\hline Age & $\begin{array}{c}-0.017^{* * *} \\
(-5.98)\end{array}$ & $\begin{array}{c}-0.017^{* * *} \\
(-6.03)\end{array}$ & $\begin{array}{c}-0.011^{* * *} \\
(-6.42)\end{array}$ & $\begin{array}{c}-0.011^{* * *} \\
(-6.41)\end{array}$ & $\begin{array}{c}-0.019^{* * *} \\
(-9.38)\end{array}$ & $\begin{array}{c}-0.019^{* * *} \\
(-9.27)\end{array}$ & $\begin{array}{c}-0.009^{* * *} \\
(-5.88)\end{array}$ & $\begin{array}{c}-0.009^{* * *} \\
(-5.85)\end{array}$ \\
\hline Year & Control & Control & Control & Control & Control & Control & Control & Control \\
\hline Ind & Control & Control & Control & Control & Control & Control & Control & Control \\
\hline Constant & $\begin{array}{c}0.098^{* * *} \\
(4.97)\end{array}$ & $\begin{array}{c}0.090^{* * *} \\
(4.47)\end{array}$ & $\begin{array}{l}0.004 \\
(0.24)\end{array}$ & $\begin{array}{l}0.006 \\
(0.31)\end{array}$ & $\begin{array}{c}0.092 * * * \\
(6.58)\end{array}$ & $\begin{array}{c}0.082^{* * *} \\
(5.75)\end{array}$ & $\begin{array}{c}-0.044^{* *} \\
(-2.53)\end{array}$ & $\begin{array}{c}-0.052^{* * *} \\
(-2.96)\end{array}$ \\
\hline $\mathrm{N}$ & 1943 & 1943 & 4177 & 4,177 & 2715 & 2715 & 4602 & 4602 \\
\hline Adi_R2 & 0.243 & 0.243 & 0.301 & 0.301 & 0.244 & 0.245 & 0.324 & 0.324 \\
\hline
\end{tabular}

Note: All the regressions control for year fixed effects. The t-statistics in parentheses are based on robust standard errors clustered at the firm level. ${ }^{*}, * *$, and ${ }^{* * *}$ indicate statistical significance at the $10 \%, 5 \%$, and $1 \%$ level, respectively.

The customer relationship mainly has a promotional effect on enterprise innovations, namely raising customer concentration significantly promotes input in enterprise innovations. The senior executives of SOEs are mostly administrative officers appointed by the government. These directors are inclined to carrying out innovative activities through the customer relationship because they are driven by goals such as promoting the construction of an innovative country, facilitating leadership of transiting the economic structure, and racing for political promotions. When customer concentration exceeds a certain threshold value, SOEs face severe agency conflicts, which make it likely for changing the intimate customer relationship into a means for SOE senior executives to make profits. In other words, SOE senior executives have power rent-seeking or transmit profits through big customer relationship, which crowds out innovative resources. With the increase in customer concentration, SOEs first increase input and then decrease input in innovations. There is a significant inverted-U-shaped tendency. Calculated by the turning point, $50 \%$ of customer concentration is favorable for the innovations of SOEs under both high and low economic policy uncertainty.

\subsubsection{Grouping by Corporate Location}

Under high economic policy uncertainty, the test results are shown in the Columns (1) to (6) of Table 7. In the group of Western China, there are significant positive correlations between customer concentration and enterprise sustainable innovations. In the group of Central China, there is a significant inverted-U-shaped relationship between customer concentration and enterprise innovations. In the group of Eastern China, there is no significant relationship between customer concentration and enterprise innovations. Under low economic policy uncertainty, there are significant positive correlations between customer concentration and enterprise innovations in the Western China group. In the Eastern China group and Central China group, there is an inverted-U-shaped relationship between customer concentration and enterprise innovations. According to the Suest test, the Top $5^{2}$ regression coefficient of Column (4) and Column (10) in Central China sees no between-group difference. The Top 5 coefficient of Western China in Column (5) and Column (10) sees no between-group difference $(\mathrm{P}>0.5715)$. 
Table 7. Customer concentration and enterprise innovation (grouped by the location).

\begin{tabular}{|c|c|c|c|c|c|c|c|c|c|c|c|c|}
\hline & \multicolumn{6}{|c|}{ High Epu } & \multicolumn{6}{|c|}{ Low Epu } \\
\hline & \multicolumn{2}{|c|}{ Eastern China } & \multicolumn{2}{|c|}{ Central China } & \multicolumn{2}{|c|}{ Western China } & \multicolumn{2}{|c|}{ Eastern China } & \multicolumn{2}{|c|}{ Central China } & \multicolumn{2}{|c|}{ Western China } \\
\hline & (1) & (2) & (3) & $(4)$ & (5) & $(6)$ & (7) & (8) & (9) & (10) & (11) & (12) \\
\hline & R\&D & R\&D & R\&D & R\&D & R\&D & R\&D & R\&D & R\&D & R\&D & $R \& D$ & $R \& D$ & $R \& D$ \\
\hline \multirow[t]{2}{*}{ Top5 } & 0.004 & 0.004 & 0.009 & $0.047^{* * *}$ & $0.015^{* *}$ & 0.026 & 0.000 & $0.018^{* *}$ & 0.000 & $0.042 * * *$ & $0.020 * * *$ & $0.043^{* * *}$ \\
\hline & (1.32) & $(0.41)$ & (1.62) & -2.66 & $(2.05)$ & $(1.19)$ & $(0.19)$ & $(2.05)$ & $(0.01)$ & $(3.06)$ & (3.26) & $(2.76)$ \\
\hline \multirow[t]{2}{*}{ Top $5^{2}$} & & -0.000 & & $-0.043 * *$ & & -0.013 & & $-0.021^{* *}$ & & $-0.050^{* * *}$ & & -0.027 \\
\hline & & $(-0.02)$ & & $(-2.08)$ & & $(-0.52)$ & & $(-2.04)$ & & $(-3.07)$ & & $(-1.58)$ \\
\hline \multirow[t]{2}{*}{ Size } & 0.001 & 0.001 & $0.003 *$ & 0.003 ** & $0.002 *$ & $0.002 *$ & $0.002^{* * *}$ & $0.002^{* * *}$ & 0.001 & 0.001 & 0.001 & 0.001 \\
\hline & $(0.91)$ & $(0.90)$ & (1.86) & -2.29 & (1.69) & (1.73) & (3.13) & (3.51) & $(0.49)$ & $(0.95)$ & $(1.11)$ & $(1.26)$ \\
\hline \multirow[t]{2}{*}{ Lev } & $-0.047^{* * *}$ & $-0.047^{* * *}$ & $-0.043^{* * *}$ & $-0.044^{* * *}$ & $-0.034^{* * *}$ & $-0.034^{* * *}$ & $-0.052^{* * *}$ & $-0.052^{* * *}$ & $-0.031^{* * *}$ & $-0.032^{* * *}$ & $-0.033^{* * *}$ & $-0.033^{* * *}$ \\
\hline & $(-11.16)$ & $(-11.16)$ & $(-5.19)$ & $(-5.30)$ & $(-4.02)$ & $(-4.01)$ & $(-13.81)$ & $(-13.85)$ & $(-3.91)$ & $(-4.11)$ & $(-4.83)$ & $(-4.83)$ \\
\hline \multirow[t]{2}{*}{ TobinQ } & $0.004^{* * *}$ & $0.004^{* * *}$ & $0.005^{* * *}$ & $0.005^{* * *}$ & $0.005^{* * *}$ & $0.005^{* * *}$ & $0.005^{* * *}$ & $0.005^{* * *}$ & $0.004^{* * *}$ & $0.004^{* * *}$ & $0.004^{* * *}$ & $0.004^{* * *}$ \\
\hline & $(7.04)$ & (7.01) & (3.30) & -3.4 & (3.74) & (3.76) & $(11.30)$ & (11.41) & (3.19) & (3.31) & $(2.79)$ & $(2.76)$ \\
\hline \multirow[t]{2}{*}{ Roa } & $-0.089^{* * *}$ & $-0.089^{* * *}$ & $-0.105^{* * *}$ & $-0.108^{* * *}$ & $-0.134^{* * *}$ & $-0.133^{* * *}$ & $-0.094^{* * *}$ & $-0.093^{* * *}$ & $-0.057^{*}$ & -0.058 * & $-0.093^{* * *}$ & $-0.091^{* * *}$ \\
\hline & $(-5.14)$ & $(-5.13)$ & $(-3.04)$ & $(-3.05)$ & $(-3.51)$ & $(-3.43)$ & $(-6.98)$ & $(-6.92)$ & $(-1.87)$ & $(-1.92)$ & $(-2.85)$ & $(-2.78)$ \\
\hline \multirow[t]{2}{*}{$\mathrm{Cf}$} & $-0.032^{* * *}$ & $-0.032^{* * *}$ & -0.016 & -0.011 & $-0.045^{* *}$ & $-0.044^{* *}$ & -0.003 & -0.002 & -0.011 & -0.009 & -0.023 & -0.022 \\
\hline & $(-3.45)$ & $(-3.45)$ & $(-0.92)$ & $(-0.62)$ & $(-2.58)$ & $(-2.52)$ & $(-0.45)$ & $(-0.28)$ & $(-0.75)$ & $(-0.58)$ & $(-1.62)$ & $(-1.56)$ \\
\hline \multirow[t]{2}{*}{ Age } & $-0.011^{* * *}$ & $-0.011^{* * *}$ & $-0.016^{* * *}$ & $-0.015^{* * *}$ & $-0.014^{* * *}$ & $-0.014^{* * *}$ & $-0.009^{* * *}$ & $-0.009^{* * *}$ & $-0.018^{* * *}$ & $-0.017^{* * *}$ & $-0.015^{* * *}$ & $-0.015^{* * *}$ \\
\hline & $(-6.71)$ & $(-6.72)$ & $(-4.42)$ & $(-4.35)$ & $(-3.40)$ & $(-3.37)$ & $(-6.86)$ & $(-6.84)$ & $(-5.77)$ & $(-5.63)$ & $(-4.86)$ & $(-4.75)$ \\
\hline Year & control & control & control & control & control & control & control & control & control & control & control & control \\
\hline Ind & control & control & control & control & control & control & control & control & control & control & control & control \\
\hline \multirow[t]{2}{*}{ Constant } & $0.043^{* * *}$ & $0.043^{* * *}$ & 0.026 & 0.008 & 0.004 & -0.000 & 0.011 & 0.004 & $0.053 *$ & 0.035 & 0.018 & 0.011 \\
\hline & $(2.80)$ & $(2.71)$ & $(0.87)$ & -0.26 & $(0.14)$ & $(-0.01)$ & $(0.82)$ & $(0.27)$ & $(1.81)$ & $(1.22)$ & $(0.79)$ & $(0.49)$ \\
\hline $\mathrm{N}$ & 4301 & 4301 & 1024 & 1024 & 795 & 795 & 5055 & 5055 & 1253 & 1253 & 1009 & 1009 \\
\hline Adi_R2 & 0.321 & 0.321 & 0.253 & 0.257 & 0.268 & 0.268 & 0.346 & 0.346 & 0.243 & 0.247 & 0.262 & 0.263 \\
\hline
\end{tabular}

significance at the $10 \%, 5 \%$, and $1 \%$ level, respectively. 
The reason is that East China has a complete official system, fairer element market, and better financial environment than Central and Western China under high economic policy uncertainty. Thus, enterprises in Central and Western China can get innovative resources and property right protection more easily. In the meantime, China's economic policies always tilt towards Eastern China that has a favorable investment environment to achieve the goals for economic development. Thus, the customer relationship plays an inadequate role in substituting the non-official system. It thus brings an insignificant effect in promoting enterprise sustainable innovations. By comparison, Western China has a weaker institutional environment, incomplete element market, and imperfect financial system. Thus, enterprises, which face higher financing constraints and disadvantages for getting resources, are more reliant on the interpersonal relationship network. Thus, clients' risk effect is offset by positive effects, including supply chain resource integration and technology spillover effect. Therefore, improving customer concentration in any environment plays a more significant role in promoting enterprises in Western China to input into innovations. For enterprises located in Central China, their institutional construction and market environments are better than those in Western China and worse than those in Eastern China. For this reason, the innovative advantages brought by big customer relationships are not as prominent as enterprises in Central China and Western China. As customer concentration improves, the innovation input of enterprises in Western China faces the inverted tendency of increasing at first and then decreasing. According to further calculation, it was found that the turning points of customer concentration were $54.65 \%$ and $42 \%$, respectively. In other words, the enterprises in Western China adjust the appropriate customer concentration according to changes in uncertainty.

\section{Discussion and Conclusions}

Although sustainable innovation is the engine and source of power for facilitating economic transitions and growth, the innovation behaviors of Chinese enterprises are severely restricted by the distortion of the element market and institutional arrangements in transition. Based on the institutional background that China is relationship-oriented rather than market-oriented, the paper analyzed the annual data of Chinese A-share listed companies between 2009 and 2017. It deeply excavated how client orientation affected enterprise sustainable innovations, its influential effects, as well as the differences between such impacts under different levels of economic policy uncertainty.

According to test results, firstly, the customer relationship affects enterprise innovations through the supply chain integration effect and client risk effect. There is an inverted-U-shaped relationship between customer concentration and enterprise sustainable innovations. When customer concentration is lower than $53.33 \%$, improving customer concentration generally encourages enterprises to make innovations. When customer concentration exceeds 53.33\%, improving customer concentration prevents enterprises from making innovations.

Secondly, the impact of customer concentration on sustainable innovations has heterogeneity when enterprises are under different levels of economic policy uncertainty. Under low economic policy uncertainty, there is an inverted-U-shaped relationship between customer concentration and enterprise sustainable innovations. Under high economic policy uncertainty, the supply chain integration advantage of the customer relationship can be maximized. Also, raising client concentration significantly promotes enterprise sustainable innovations.

Lastly, under different levels of economic policy uncertainty, customer concentration affects enterprise innovations differently as the nature of property rights and locations of enterprises vary. Thus, the interval of customer concentration conducive for corporate innovations also differs. If SOEs keep $50 \%$ of customer orientation, it will be conducive for enterprise sustainable innovations. If the economic policy uncertainty is high, non-SOEs should work hard to raise customer concentration and make the most of the resources brought by the customer relationship. Client concentration has a significantly more positive impact on the R\&D input of enterprises in Eastern China than enterprises in Western China. Enterprises in Western China may develop large clients and raise client concentration 
to get innovation resources from cooperative partners on supply chains. Enterprises in Central China should appropriately adjust the interval of customer concentration according to environmental uncertainty to promote enterprise sustainable innovations.

The theoretical implications are threefold. Firstly, strong customer-supplier relationships encourage suppliers to increase their relationship-specific and R\&D investments [74], consistent with predictions in the transaction cost economics (TCE) theory developed by Williamson [75]. Secondly, based on institutional theory, this paper extends the notion that heterogeneous institutional environments and their differential institutional environmental uncertainty can make organizations behave heterogeneously [51-53]. In this vein, particularly in a large transition economy such as China, as a level of institutional uncertainty becomes higher, the institutional support strengthens for major enterprises with a tight network relationship with highly concentrated major customers. Lastly, the finding might theoretically imply that because of potentially high customer switching costs driven by relationship-specific investments, suppliers are more actively engaged in research and product development as a defensive strategy to maintain their competitive position in the product market.

This paper helps to understand how customer concentration affects enterprise sustainable innovations and their relevant effects. Besides, it provides several practical and policy implications for corporate top management teams (TMTs) and current policy formulators with certain experience reference and proof support. Firstly, it is necessary to encourage and guide enterprises and their TMTs to enhance cooperation with other enterprises on the upper- and lower-streams of supply chains and offer resource advantages for enterprise sustainable innovations. However, an appropriate customer concentration should be achieved to give play to the supply-chain integration effect and to avoid the customer risk effect as much as possible.

Secondly, under different levels of economic policy uncertainty, enterprises and their TMTs should actively adjust the customer relationship, construct and maintain an appropriate customer concentration to promote enterprise sustainable innovations. Meanwhile, the government should frequently launch or adjust economic policies, which lead to severe negative impacts on enterprises. Thus the government should make macroscopic policies more predictable, construct a good external environment, and better stimulate the innovation vitality of enterprises.

Thirdly, the differences between the resource endowment and governance mechanisms of enterprises with different property rights affect the innovation effect of customer concentration. Thus, the customer relationship is likely to be changed into the means for senior executors of SOEs to get profits. It is necessary to reduce government intervention and improve the governance mechanism of modern companies. Besides, more efforts should be made to accelerate perfecting the institutional environment, to promote the element market and financial market to develop, and to improve the allocation efficiency of the capital market. It is used to improve operating conditions for enterprises in different regions and enhance their innovation abilities.

Fourthly, the paper provides new thoughts for investors and creditors to evaluate corporate values from the perspective of supply chains. Also, it helps relevant Chinese institutions to supervise corporate behaviors.

Last but not least, the paper reveals the fact that customer concentration affects enterprise innovations differently under different levels of economic policy uncertainty. It not only set up the bridge between the macroscopic policy environment and microscopic corporate behaviors but also provides enterprises with decision-making reference for constructing and maintaining real-time supply chain relationships according to the changes in the policy environment. Furthermore, it provides China's securities market with new thoughts for supervising corporate behaviors from the perspective of supply chain relationships.

Despite the contributions of this study, we still have some limitations and further research accordingly. First, Zhou et al. [40] explored "how customer concentration affects the innovation activities of enterprises, considering both an internal factor (managers' expectation) and an external factor (financial constraint)" (p. 13). However, our study does not consider these internal and external 
factors in our conceptual model; thus, future research in in relation to these factors can be needed. Second, Chen [76] proposed "a theoretical model, dividing enterprise sustainable innovation ability into three aspects: knowledge innovation capability, production innovation capability, and market innovation capability" (p. 1). Yet, our study does not include these detailed aspects as Chen did, so in future research these three aspects can be included in the conceptual model.

Author Contributions: Conceptualization, T.Z. And Y.Z.; methodology, Y.Z.; software, T.Z; validation, T.Z., F.S. and J.Y.L.; formal analysis, T.Z.; investigation, Y.Z.; resources, F.S.; data curation, Y.Z.; writing—original draft preparation, T.Z.; writing - review and editing, J.Y.L.; visualization, J.Y.L.; supervision, F.S.; project administration, F.S.; funding acquisition, F.S. All authors have read and agreed to the published version of the manuscript.

Funding: This research is partially sponsored by the National Social Science Fund of China Project (17XJY007), Key Research Base of Humanities and Social Sciences of the Ministry of Education Major Project (19JJD790011), Chongqing Federation of Social Science Project (2018YBGL052) and Science and Technology Research Program of Chongqing Education Commission (KJQN201900835).

Conflicts of Interest: The authors declare no conflict of interest.

\section{References}

1. Banerjee, S.; Dasgupta, S.; Kim, Y. Buyer-supplier relationships and the stakeholder theory of capital structure. J. Financ. 2008, 63, 2507-2552. [CrossRef]

2. Chu, Y. Optimal capital structure, bargaining, and the supplier market structure. J. Financ. Econ. 2012, 106, 411-426. [CrossRef]

3. Cunat, V. Trade credit: Suppliers as debt collectors and insurance providers. Rev. Financ. Stud. 2007, 20, 491-527. [CrossRef]

4. Garcia-Appendini, E.; Montoriol-Garriga, J. Firms as liquidity providers: Evidence from the 2007-2008 financial crisis. J. Financ. Econ. 2013, 109, 272-291. [CrossRef]

5. Kale, J.; Shahrur, H. Corporate capital structure and the characteristics of the supplier customer markets. J. Financ. Econ. 2007, 83, 321-365. [CrossRef]

6. Petersen, M.A.; Rajan, R.G. Trade credit: Theories and evidence. Rev. Financ. Stud. 1997, 10, 661-691. [CrossRef]

7. Titman, S.; Wessels, R. The determinants of capital structure choice. J. Financ. 1988, 43, 1-19. [CrossRef]

8. Itzkowitz, J. Customers and cash: How relationships affect suppliers' cash holdings. J. Corp. Financ. 2013, 19, 159-180. [CrossRef]

9. Wilner, B.S. The exploitation of relationships in financial distress: The case of trade credit. J. Financ. 2000, 55, 153-178. [CrossRef]

10. Raman, K.; Shahrur, H. Relationship-specific investment and earnings management: Evidence on corporate suppliers and customers. Account. Rev. 2008, 83, 1041-1081. [CrossRef]

11. Hui, K.W.; Klasa, S.; Yeung, P.E. Corporate suppliers and customers and accounting conservatism. J. Account. Econ. 2012, 53, 115-135. [CrossRef]

12. Ahern, K.R. Bargaining power and industry dependence in mergers. J. Financ. Econ. 2012, 103, 530-550. [CrossRef]

13. Ahern, K.R.; Harford, J. The importance of industry links in merger waves. J. Financ. 2014, 69, 527-576. [CrossRef]

14. Bhattacharyya, S.; Nain, A. Horizontal acquisitions and buying power: A product market analysis. J. Financ. Econ. 2011, 99, 97-115. [CrossRef]

15. Fee, C.E.; Thomas, S. Sources of gains in horizontal mergers: Evidence from customer, supplier, and rival firms. J. Financ. Econ. 2004, 74, 423-460. [CrossRef]

16. Shahrur, H. Industry structure and horizontal takeovers: Analysis of wealth effects on rivals, suppliers, and corporate customers. J. Financ. Econ. 2005, 76, 61-98. [CrossRef]

17. Cohen, L.; Frazzini, A. Economic links and predictable returns. J. Financ. 2008, 63, 1977-2011. [CrossRef]

18. Boone, A.L.; Ivanov, V.I. Bankruptcy spillover effects on strategic alliance partners. J. Financ. Econ. 2012, 103, 551-569. [CrossRef]

19. Hertzel, M.G.; Li, Z.; Officer, M.; Rodgers, K. Inter-firm linkages and the wealth effects of financial distress along the supply chain. J. Financ. Econ. 2008, 87, 374-387. [CrossRef] 
20. Dhaliwal, D.; Judd, J.S.; Serfling, M.; Shaikh, S. Customer concentration risk and the cost of equity capital. J. Account. Econ. 2016, 61, 23-48. [CrossRef]

21. Akcigit, U.; Ates, S.T. Ten facts on declining business dynamism and lessons from endogenous growth theory. Natl. Bur. Econ. Res. 2019. [CrossRef]

22. Romer, P.M. The origins of endogenous growth. J. Econ. Perspect. 1994, 8, 3-22. [CrossRef]

23. Barro, R.J.; Sala-i-Martin, X. Economic Growth, 2nd ed.; McGraw-Hill: New York, NY, USA, 2004.

24. Acemoglu, D. Introduction to Modern Economic Growth; Princeton University Press: Princeton, NJ, USA, 2009.

25. Chao, L.Q.L.X.G. Informal institutional protection and innovation expense: Evidence from listed private firms in China. Nankai Econ. Stud. 2011, 3. Available online: http://en.cnki.com.cn/Article_en/CJFDTotalNKJJ201103009.htm (accessed on 30 December 2019).

26. Li, Z. The governance role of accounting in relationship-based transactions: Paradigm exploration of internationalized China. Financ. Res. 2017, 2, 4-33.

27. Itzkowitz, J. Buyers as stakeholders: How relationships affect suppliers' financial constrains. J. Corp. Financ. 2015, 31, 54-66. [CrossRef]

28. Chen, J.; Wang, X.Y.; Peng, X. Environment uncertainty, customer concentration and cost of equity capital. Account. Res. 2016, 11, 76-82.

29. Xue, S.; Yao, Y.; Wang, X. Concentration of the supply chain and audit opinion shopping: The case of China. Chin. J. Account. Stud. 2018, 6, 135-158. [CrossRef]

30. Li, N.; Yang, Z. Customer relationship and debt contracting. Work. Pap. 2011. [CrossRef]

31. Chu, J.; Fang, J. Dose customer concentration rise or reuse firms' crash risk. Econ. Theory Econ. Manag. 2016, 7, 44-57.

32. Piercy, N.; Lane, N. The underlying vulnerabilities in key account management strategies. Eur. Manag. J. 2006, 24, 151-162. [CrossRef]

33. Yue-jun, T. Bargaining power of suppliers and buyers, and corporate performance-Evidence from Chinese manufacturing listed companies from 2005 to 2007. Chin. Ind. Econ. 2009, 10. Available online: http: //en.cnki.com.cn/Article_en/CJFDTotal-GGYY200910007.htm (accessed on 30 December 2019).

34. Wang, J. Do firms' relationships with principal customers/suppliers affect shareholders' income? J. Corp. Financ. 2012, 18, 860-878. [CrossRef]

35. Gulen, H.; Ion, M. Policy uncertainty and corporate investment. Rev. Financ. Stud. 2016, $29,523-564$. [CrossRef]

36. Acemoglu, D.; Johnson, S.; Mitton, T. Determinants of vertical integration: Financial development and contracting costs. J. Financ. 2009, 64, 1251-1290. [CrossRef]

37. Dass, N.; Kale, J.R.; Nanda, V. Trade credit, relationship-specific investment, and product market power. Rev. Financ. 2014, 19, 1867-1923. [CrossRef]

38. Walter, A. Relationship-specific factors influencing supplier involvement in customer new product development. J. Bus. Res. 2003, 56, 721-733. [CrossRef]

39. Chang, H.; Hall, C.; Paz, M.T. Customer concentration and cost structure. SSRN Electron. J. 2015. Available online: https://papers.ssrn.com/sol3/papers.cfm?abstract_id=2482777 (accessed on 30 December 2019).

40. Zhou, B.; Li, Y.; Huang, S.; Guo, S.; Xue, B. Customer concentration and corporate innovation: Effects of financing constraints and managers' expectation of Chinese listed companies. Sustainability 2019, 11, 2859. [CrossRef]

41. Ju, X.; Lo, D.; Yu, Y. Financial constraints, working capital management, and the sustainability of firm innovation. Econ. Res. J. 2013, 48, 4-16.

42. Davis, G.F.; Cobb, J. Resource dependence theory: Past and future. Res. Soc. Organ. 2010, 28, $21-42$.

43. Hillman, A.J.; Withers, M.C.; Collins, B.J. Resource dependence theory: A review. J. Manag. 2009, 35, 1404-1427. [CrossRef]

44. Pfeffer, J.; Salancik, G.R. The External Control of Organizations: A Resource Dependence Perspective; Harper and Row: New York, NY, USA, 1978.

45. Xu, H.; Lin, Z.G.; Chen, R. Customer relationship and R\&D investment decisions. Collect. Essay Financ. Econ. 2016, 203, 1.

46. Zhang, F.-H. Firm's social capital and S\&T innovation performance: Concept model and empirical analysis. R D Manag. 2006, 18, 47-53. 
47. Chen, Z.L. Customer concentration, government intervention and company risk. Account. Res. 2016, 11, 23-29, 95.

48. Jiang, T.; Zhang, Y.J.; Zhao, X.L. Uncertainty of economic policy and corporate debt financing. Manag. Rev. 2018, 30, 29-39.

49. Li, F.Y.; Yang, M.Z. Will the uncertainty of economic policy restrain the investment of enterprises-An Empirical Study Based on the uncertainty index of China's economic policy. J. Financ. Res. 2015, 4, 115-129.

50. Gu, X.M.; Chen, Y.M.; Pan, S.Y. Uncertainty and innovation of economic policy-Based on the empirical analysis of Listed Companies in China. Econ. Res. J. 2018, 2, 109-123.

51. Luk, C.-L.; Yau, O.H.M.; Sin, L.Y.M.; Tse, A.C.B.; Chow, R.P.M.; Lee, J.S.Y. The effects of social capital and organizational innovativeness in different institutional contexts. J. Int. Bus. Stud. 2008, 39, 589-612. [CrossRef]

52. DiMaggio, P.J.; Powell, W.W. The iron cage revisited: Institutional isomorphism and collective rationality in organizational fields. Am. Soc. Rev. 1983, 48, 147-160. [CrossRef]

53. North, D. Institutions, Institutional Change, and Economic Performance; Harvard University Press: Cambridge, MA, USA, 1990.

54. Puffer, S.M.; McCarthy, D.J. Can Russia's state managed, network capitalism be competitive? Institutional pull versus institutional push. J. World Bus. 2007, 42, 1-13. [CrossRef]

55. Tsai, W.; Ghoshal, S. Social capital and value creation: The role of intrafirm networks. Acad. Manag. J. 1998, 41, 464-476.

56. Matsumura, E.M.; Schloetzer, J.D. The structural and executional components of customer concentration: Implications for supplier performance. J. Manag. Account. Res. 2018, 30, 185-202. [CrossRef]

57. Feng, G.; Wen, J. An empirical analysis of the relationship between corporate governance and Enterprise technological innovation of Listed Companies in China. Chin. Ind. Econ. 2008, 7, 91-101.

58. Hao, W.Y.; Wei, W.; Wen, J. How does the uncertainty of economic policy affect the innovation of enterprises?-A perspective of the mechanism of real option theory. Bus. Manag. J. 2016, 10, 40-54.

59. Rao, P.G.; Xu, Z.H. Does the uncertainty of economic policy affect the change of executives? Manag. World 2017, 1, 145-157.

60. Baker, S.R.; Bloom, N.; Davis, S.J. Measuring economic policy uncertainty. Q. J. Econ. 2016, 131, $1593-1636$. [CrossRef]

61. Meng, Q.X.; Bai, J.; Shi, W. Customer concentration and enterprise technology innovation: Help or hinder-A Study based on the individual characteristics of customers. Nankai Bus. Rev. 2018, 21, 62-73.

62. Meng, Q.B.; Shi, Q. The impact of macroeconomic policy uncertainty on enterprise R\&D: Theoretical and empirical studies. J. World Econ. 2017, 9, 75-98.

63. Jie, W.M.; Fang, H.X. Financial development, financing constraints and R\&D investment of enterprises. J. Financ. Res. 2011, 5, 171-183.

64. Liu, Y.G.; Liu, W. Executive tenure and R \& D expenditure of Listed Companies in China. Manag. World 2007, 1, 128-136.

65. Razali, N.; Wah, Y.B. Power comparisons of Shapiro-Wilk, Kolmogorov-Smirnov, Lilliefors and Anderson-Darling tests. J. Stat. Model. Anal. 2011, 2, 21-33.

66. Krolikowski, M.; Yuan, X. Friend or foe: Customer-supplier relationships and innovation. J. Bus. Res. 2017, 78, 53-68. [CrossRef]

67. Panousi, V.; Papanikolaou, D. Investment, idiosyncratic risk, and ownership. J. Financ. 2012, 67, $1113-1148$. [CrossRef]

68. Chen, Z. Supplier innovation in the presence of buyer power. Int. Econ. Res. 2019, 60, 329-353. [CrossRef]

69. Czarnitzki, D.; Toole, A.A. Patent protection, market uncertainty, and R\&D investment. Rev. Econ. Stat. 2011, 93, 147-159.

70. Sun, Y.; Wen, K. Uncertainties, imitative behaviours and foreign R\&D location: Explaining the over-concentration of foreign R\&D in Beijing and Shanghai within China. Asia Pac. Bus. Rev. 2007, 13, 405-424.

71. Van Vo, L.; Le, H. Strategic growth option, uncertainty, and R\&D investment. Int. Rev. Financ. Anal. 2017, 51, 16-24.

72. Cao, Y.; Sun, L.; Cu, W.H. Customer concentration, internal control quality and corporate tax avoidance. Audi. Res. 2018, 1, 120-128. 
73. Wang, Y.Z.; Luo, N.S.; Liu, W.B. What kind of leverage is conducive to enterprise innovation. Chin. Ind. Econ. 2019, 3, 138-155.

74. Schwabe, T. Transaction cost economics in supply chain management. In Proceedings of the 1st IBA Bachelor Thesis Conference, Enschede, The Netherlands, 27 June 2013.

75. Williamson, O. Transaction-cost economics: The governance of contractual relations. J. Law Econ. 1979, 22, 233-261. [CrossRef]

76. Chen, S.H. The influencing factors of enterprise sustainable innovation: An empirical study. Sustainability 2016, 8, 425. [CrossRef]

(C) 2020 by the authors. Licensee MDPI, Basel, Switzerland. This article is an open access article distributed under the terms and conditions of the Creative Commons Attribution (CC BY) license (http://creativecommons.org/licenses/by/4.0/). 